\title{
Estimating the Impact of the Hajj: Religion and Tolerance in Islam's Global Gathering
}

\section{Citation}

Clingingsmith, David, Asim ljaz Khwaja, and Michael R. Kremer. 2009. Estimating the impact of the Hajj: Religion and tolerance in Islam's global gathering. Quarterly Journal of Economics 124(3): 1133-1170.

\section{Published Version}

http://dx.doi.org/10.1162/qjec.2009.124.3.1133

\section{Permanent link}

http://nrs.harvard.edu/urn-3:HUL.InstRepos:3659699

\section{Terms of Use}

This article was downloaded from Harvard University's DASH repository, and is made available under the terms and conditions applicable to Other Posted Material, as set forth at http:// nrs.harvard.edu/urn-3:HUL.InstRepos:dash.current.terms-of-use\#LAA

\section{Share Your Story}

The Harvard community has made this article openly available.

Please share how this access benefits you. Submit a story.

\section{Accessibility}




\title{
Estimating the Impact of the Haji:
}

\section{Religion and Tolerance in Islam's Global Gathering}

\author{
David Clingingsmith, Asim Ijaz Khwaja, and Michael Kremer*
}

July 2008

\begin{abstract}
We estimate the impact on pilgrims of performing the Hajj pilgrimage to Mecca. Our method compares successful and unsuccessful applicants in a lottery used by Pakistan to allocate Hajj visas. Pilgrim accounts stress that the Hajj leads to a feeling of unity with fellow Muslims, but outsiders have sometimes feared that this could be accompanied by antipathy toward non-Muslims. We find that participation in the Hajj increases observance of global Islamic practices, such as prayer and fasting, while decreasing participation in localized practices and beliefs, such as the use of amulets and dowry. It increases belief in equality and harmony among ethnic groups and Islamic sects and leads to more favorable attitudes toward women, including greater acceptance of female education and employment. Increased unity within the Islamic world is not accompanied by antipathy toward non-Muslims. Instead, Hajjis show increased belief in peace, and in equality and harmony among adherents of different religions. The evidence suggests that these changes are likely due to exposure and interaction with Hajjis from around the world, rather than a changed social role of pilgrims upon return.
\end{abstract}

JEL codes: D74, D02, D83, Z12, Z13

Keywords: Religion, Institutions, Social Interaction, Identity, Beliefs.

\footnotetext{
* Clingingsmith: Department of Economics, Weatherhead School of Management, Case Western Reserve University; dlc43@case.edu. Khwaja: Kennedy School of Government, Harvard University; akhwaja@ksg.harvard.edu. Kremer: Department of Economics, Harvard University, the Brookings Institution, and NBER; mkremer@ffas.harvard.edu. This paper has benefited from discussions with Alberto Abadie, May Al-Dabbagh, Tahir Andrabi, Ali Asani, Eli Berman, Amitabh Chandra, Lou Christillo, Jamal Elais, Carl Ernst, Raymond Fisman, Ed Glaeser, Bill Graham, Hamid Hasan, Sohail Hashimi, Zoe Hersov, Alaka Holla, Larry Iannaconne, Guido Imbens, Emir Kamenica, Ijaz A. Khwaja, Charles Kurzman, Erzo Luttmer, Brigitte Madrian, Rachel McCleary, Atif Mian, Rohini Pande, Barbara von Schlegel, Eldar Shafir, Nasim Sherazi, Tarik Yousef, Asad Zaman, and seminar audiences at Harvard University, Georgetown University, the University of Southern California, the London School of Economics, University College London, the Dubai School of Government, Stanford University, the University of California-Berkeley, Tufts University, Case Western Reserve University, University of Pennsylvania, University of Chicago, Columbia University, Ohio State University, the $6^{\text {th }}$ ASREC conference, the NBER National Security Working Group and Political Economy Meetings, and the International Islamic University Islamabad. Erin Baggott, Katalin Blankenship, Dan Choate, Alexandra Cirone, Benjamin Feigenberg, Martin Kanz, Supreet Kaur, Bilal Malik, Jeanette Park and most notably Hisham Tariq provided excellent research assistance. We thank the editor, Ed Glaeser, the second editor and three anonymous referees for comments. We gratefully acknowledge financial support for this project from the Spiritual Capital Research Program of the Metanexus Foundation and the Weatherhead Center for International Affairs at Harvard University. Khwaja thanks the Dubai Initiative at the Kennedy School, the William F. Milton Fund and the HKS Dean's Research Fund for financial support. We also thank Pakistan's Ministry of Religious Affairs for graciously sharing data.
} 


\section{Introduction}

We take advantage of a lottery used by Pakistan to allocate visas for the Hajj pilgrimage to understand the impact of the Hajj on pilgrims' attitudes, beliefs, and practices. Our work sheds light on contemporary concerns regarding Islamic orthodoxy and extremism by showing that while the Hajj increases observance of orthodox Islamic practices, it also increases the desire for peace and tolerance towards others, both Muslims and non-Muslims. Our study also contributes to a broader literature on theories of social interaction and social identity and on the role of religious institutions.

During five specific days each year, more than two million Muslim men and women from over a hundred different countries gather in Mecca for the Hajj, often staying for over a month. Pilgrims mix across the lines of ethnicity, nationality, sect, and gender that divide them in everyday life. They affirm a common identity by communally performing identical rituals and dressing in similar garments that emphasize their equality.

Numerous pilgrim accounts suggest that the Hajj inspires feelings of unity with the worldwide Muslim community (Wolfe, 1997). Malcolm X performed the Hajj after breaking from the heterodox Nation of Islam to become a Sunni Muslim. In a letter from Mecca, he wrote: "There were tens of thousands of pilgrims, from all over the world... We were all participating in the same ritual, displaying a spirit of unity and brotherhood that my experiences in America had led me to believe never could exist between the white and non-white... [W] hat I have seen, and experienced, has forced me to rearrange much of my thought-patterns previously held, and to toss aside some of my previous conclusions" (Malcolm X with Haley, 1965).

Some have worried, though, that by promoting greater unity among Muslims, the Hajj could have negative implications for non-Muslims. After it emerged that some of the July $7^{\text {th }}$ bombers of the London public transport system had undertaken the Hajj, the British intelligence services began monitoring pilgrims (Sunday Times, 2007). Historically, colonial authorities also expressed similar concerns regarding the Hajj (Bose 2006, Low 2007).

Yet others have expressed concern that the Hajj promotes a particular type of Islam. For example, Naipaul (1981) laments what he sees as the erosion of local religious traditions in South Asian Islam in favor of a more Saudi or Arab version of Islam.

Of course, it is difficult to isolate the causal impact of the Hajj based on examples like those of Malcolm X or the July $7^{\text {th }}$ bombers. Those who choose to undertake the Hajj differ from those who do not, and the choice to do so may reflect other life changes. Thus, changes in pilgrims' views and 
behavior after the Hajj may not reflect its impact. We estimate the effect of performing the Hajj by comparing successful and unsuccessful applicants to a lottery Pakistan uses to allocate its limited supply of Hajj visas. Since our survey included 1600 Pakistani Sunni Hajj visa applicants and was conducted five to eight months after the completion of the Hajj, our results should be interpreted as isolating the medium-term impact of performing the Hajj on this particular population.

Our results support the idea that the Hajj helps to integrate the Muslim world, leading to a strengthening of global Islamic beliefs, a weakened attachment to localized religious customs, and a sense of unity and equality with others who are ordinarily separated in everyday life by sect, ethnicity, nationality, or gender, but who are brought together during the Hajj. While the Hajj may help forge a common Islamic identity, there is no evidence that this is defined in opposition to nonMuslims. On the contrary, the notions of equality and harmony appear to extend to adherents of other religions as well. These results contrast sharply with the view that increased Islamic orthodoxy goes hand in hand with extremism.

We find that Hajjis (those who have performed the Haji) are more likely to undertake universally accepted global Muslim religious practices such as fasting and performing obligatory and supererogatory (optional) prayers. In contrast, the Hajj reduces performance of less universally accepted, more localized practices and beliefs such as using amulets and the necessity of giving dowry. For example, the Hajj increases regularly praying in the mosque by $26 \%$ and almost doubles the likelihood of non-obligatory fasting. At the same time, it reduces the practice of using amulets by $8 \%$ and the South Asian belief of according unequal marriage priority to widows relative to unmarried women by $18 \%$.

The evidence suggests that the Hajj increases tolerance both within the Islamic world but also beyond it. Hajjis return with more positive views towards people from other countries. Hajjis are also more likely to state that various Pakistani ethnic and Muslim sectarian groups are equal, and that it is possible for such groups to live in harmony. These views of equality and harmony extend to non-Muslims as well: Hajjis are 22\% more likely to declare that people of different religions are equal and $11 \%$ more likely to state that adherents of different religions can live in harmony.

We also find evidence that Hajjis are more peacefully inclined. For example, while few in our sample are willing to openly condemn the goals of Osama Bin Laden, Hajjis are almost twice as likely to do so. Hajjis are also more likely to express a preference for peace with India and are 17\% more likely to declare that it is incorrect to physically punish someone who has dishonored the family. 
There is little evidence that participating in the Hajj increases support for an increased role of religion in the state or politics, or that it induces negative views of the West. Hajjis are in fact less likely to believe that the state should enforce religious injunctions and that religious leaders should be able to dispense justice. Hajjis and non-Hajjis report similar views regarding the adoption of Western values and on the plausibility of Western/Jewish roles in the September 11 th and July $7^{\text {th }}$ terrorist attacks.

The feelings of unity and equality brought about by the Hajj extend across gender lines to an extent. Hajjis report more positive views on women's attributes and abilities. For example, they are 6 percentage points more likely to think women are spiritually better than men, an increase of over $50 \%$. They also express greater concern about women's quality of life in Pakistan relative to other countries and about crimes against women in Pakistan. Hajjis are also more likely to support girls' education and female participation in the professional workforce. Hajjis show an $8 \%$ increase in their declared preference for their daughters or granddaughters to adopt professional careers. Male Hajjis show similar changes in views to female Hajjis. However, not all views on gender change. In particular, Hajjis are no more likely to question Islamic doctrine, such as unequal inheritance laws across gender, or to express views that potentially challenge male authority within the household, such as the correctness of a woman divorcing her husband. This suggests that Pakistani Hajjis' altered views on women reflect a movement away from local prejudices against women and towards fairer treatment within Islam, rather than a more general trend towards feminism.

Hajjis, primarily women, report lower levels of emotional and physical well being. This may be due to the physically taxing nature of the Hajj rituals, as well as changed beliefs and greater awareness of the Muslim world outside Pakistan, particularly for women.

Contrary to some of the historical literature on the Hajj (c.f. Azarya, 1978; Donnan, 1989; Yamba, 1995), we do not find evidence in our sample of major changes, at least in the medium term, in the social role or engagement of Hajjis after their return.

While our study cannot definitively determine what drives the impact of the Hajj, further evidence suggests that the results are not driven by changes in pilgrims' social role upon return but rather reflect changes the pilgrim experiences during the Hajj, particularly exposure to Muslims from around the world. Hajjis gain experiential knowledge of the diversity of Islamic practices and beliefs, gender roles within Islam, and, more broadly, the world beyond Pakistan. While the Hajj effects could be driven by a change in religious commitment, we do not find that Hajjis acquire greater formal religious knowledge. The Hajj's impact on experiential knowledge and on some of the tolerant attitudes toward other groups tends to be larger for those traveling in smaller groups, who 
are more likely to have a broad range of social interactions with people from different backgrounds during the Hajj. Hajjis also show the largest positive gain in their views of other nationalities for Indonesians, the non-Saudi group they are most likely to observe during the Hajj. Hajjis' changed views toward women may also reflect an exposure channel since the Hajj offers Pakistani pilgrims a novel opportunity to interact with members of the opposite gender in a religious setting, and to observe cross-gender interactions among Muslims from nations more accepting of such interactions.

Our results shed light on contempory concerns about Islamic orthdoxy and extremism. For many in the West the link is apparent: $45 \%$ of Americans believe Islam is more likely to encourage violence than other religions and close to a third use negative words like fanatic, radical and terror to describe their impressions of Islam (Pew Forum Survey, 2007). It is noteworthy that while the Hajj leads to greater religious orthodoxy, it also increases pilgrims' desire for peace and tolerance towards others, Muslims and non-Muslims.

Our results also connect to a broad, longstanding literature on social interaction and the shaping of beliefs and identity. Laboratory experiments suggest that group interactions exacerbate conflict in competitive settings and lessen it in cooperative ones (Aronson and Patnoe, 1997; Johnson and Johnson, 1983; DeVries and Slavin, 1978; Slavin and Cooper, 1999; Pettigrew and Tropp, 2006; Stephan, 1978). Drawing on a particular real-world setting, Boisjoly et al. (2006) report evidence that exposure to African-American roommates generates more positive attitudes toward AfricanAmericans among white students. In contrast, Fisman et al (2008) find that exposure to a different race in youth makes individuals less likely to prefer that race for a potential mate as adults. While social identity theory suggests that strengthening attachment to an in-group may lead to negative feelings towards an out-group (Sherif et. al. 1954; Tajfel, 1970; Tajfel and Turner, 1986), our evidence shows that Hajjis also positively update their views both towards groups to which they were exposed to and those they were not.

Our findings also relate to a question in the sociology and economic modeling of religion about why religions often incorporate individually costly practices, and more broadly about the impact of religion on development (Barro and McCleary, 2003; Berman, 2000; Glaeser and Glendon, 1998; Guiso et al, 2003; Iannacone 1992; Sacerdote and Glaeser, 2001). Putnam (2007) suggests that, in the US context, religion may play a particularly important role as "glue" that builds social capital. Our results suggest that the Hajj may play a role in contributing to the survival of Islam as a unified world religion. Over time, religions with far-flung adherents tend to evolve separate strands. Absent a central hierarchy in Islam, the Hajj may help bind the Islamic world together by moving Hajjis toward a common set of practices, making them more tolerant of others, and by creating a stronger shared identity. 
Further work would be needed to determine the extent to which our findings generalize beyond the specific context we examine. Our survey, conducted five to eight months after the Hajj, captures medium term effects. While it remains open whether these effects persist, we find few changes over the survey period. Further examination is also needed to determine the extent to which the results generalize beyond our sample of Pakistani Hajj lottery applicants. For example, the impact of the Hajj on gender attitudes may be smaller for pilgrims from countries with more liberal gender views. To the extent that the gender results reflect a convergence to the mean views of Hajjis, the Hajj may even induce more conservative views for pilgrims from these countries. Moreover, nearly half of lottery applicants are illiterate. While this is fairly representative of Pakistan and a large number of Muslim countries, results could differ in more educated societies. Finally, we assess the impact of the Hajj using survey questions, several of which elicit self-reported beliefs and opinions. Additional work is needed to determine how the Hajj would impact pilgrims' actions.

The remainder of this paper is organized as follows. Section 2 gives some background on the Hajj, focusing on aspects that contextualize our findings. Section 3 lays out our statistical approach, outlines aspects of the visa application process that are important for our identification strategy, and gives details of the survey. Section 4 presents the main empirical results on religious practice and belief, tolerance, gender, and well-being. Section 5 explores potential channels for the observed effects. Section 6 concludes with some underpinnings and broader implications of our results.

\section{The Hajj Experience}

The pilgrimage to Mecca is one of the five pillars of Islam and is obligatory for those with sufficient financial means. Many Hajjis describe it as the most significant religious event in their lives. Although the Hajj rituals last five days, many pilgrims stay longer. Most of the Hajjis in our sample report spending 40 days worshipping in the cities of Mecca and Medina. ${ }^{1}$

The Hajj is an inherently communal experience, in a religion that gives particular importance to communal rituals (McCleary, 2007). Each ritual component of the Hajj is performed simultaneously with over two million participants. The focus is on individual practice rather than building religious knowledge. Moreover, each participant's performance is believed to reinforce the others', providing a shared aspect to individual worship.

The Hajj engenders substantial mixing across national, sectarian, and gender lines in an atmosphere that emphasizes equality and unity. Pilgrims' common identity is affirmed through common dress-

\footnotetext{
${ }^{1}$ See Appendix for a time-line of the Hajj and an outline of the rituals and activities.
} 
a simple white garment known as the ibram — and the communal performance of standardized ritual

practices. ${ }^{2}$ Men shave their heads, making them more similar in physical appearance, and those who complete the Hajj are entitled to use the honorific Hajji/Hajjin as a prefix to their name, further emphasizing their common identity.

While opportunities for in-depth inter-group interactions are limited both by language barriers and by the housing of pilgrims with their compatriots, the group nature of the experience makes observations of the contrasting practices and social dynamics of other groups even more salient. Close to two-thirds of the Hajjis in our survey reported frequently interacting with people from other countries during the Hajj.

The Hajj also involves more gender mixing than is typical among the Pakistani pilgrims we study. In Pakistan, interaction between men and women who are strangers is uncommon. Women rarely go to mosque and when they do, they typically pray in a separate area from men. With equal numbers of male and female Hajjis (Bianchi, 2004), such gender interactions are a natural part of the Hajj. Parties of pilgrims stay and move together for ease of planning and safety, and often include nonfamily members. Men pray alongside women, both Pakistani and non-Pakistani, during the Hajj. Our qualitative interviews revealed that these experiences were both very salient and unusual for Hajjis, and that most viewed them positively.

Finally, Hajjis are also exposed to a degree of religious diversity within the recognized schools of thought, in a religiously sanctioned context in which all are accepted. The $14^{\text {th }}$ century Muslim explorer Ibn Battuta noted that since followers of different schools of Islam prayed together at Mecca, this often led to mixing of religious practices. (Ibn Battuta, 2002 [1355]).

The Hajj is physically and financially taxing. Pilgrims travel over $80 \mathrm{~km}$, much of it typically on foot. The extreme congestion heightens risks of injury and infectious disease (Ahmed et al., 2006). Hajjis typically also sacrifice rest in order to maximize prayers during their stay. Participants in Pakistan's Hajj lottery system pay about US \$2,000 each for the trip, roughly two and half times Pakistan's 2006 per capita GDP. The median respondent in our survey saved for the Hajj for over four years.

\section{Methodology: The Hajj Lottery and Survey}

Since those who choose to perform the Hajj are likely to be motivated by a wide spectrum of unobservable and potentially time-varying factors, such as religious commitment and the desire for

${ }^{2}$ Men wear two white sheets. Women face less stringent requirements but typically also wear white. 
spiritual transformation, it is difficult to measure the impact of the Hajj by comparing Hajjis and non-Hajjis. We address this by taking advantage of a lottery that allocates Hajj visas. Since successful and unsuccessful lottery applicants are ex ante identical in expectation, we can use the lottery outcome as an instrument for whether someone performs the Hajj and isolate the Hajj impact from potential confounding factors. This section provides details of the Hajj lottery, our statistical methodology, and our survey process. ${ }^{3}$

\section{The Hajj Lottery Process}

Historically, overcrowding on the Hajj has created logistical and safety problems. Saudi Arabia, on whose territory the Hajj takes place, therefore established quotas for the number of Hajj visas available for each major Islamic country. For the January 2006 Hajj that we study, Pakistan's total quota was 150,000 visas. 90,000 visas were allocated by the government, the majority ( $89 \%$ ) by randomized lottery and the remainder by special quotas for the military and civil service. Applicants submitted a short form and deposited the Hajj fee to one of 1,559 bank branches across Pakistan between July 20 and August 15, 2005. The remaining 60,000 visas were allocated by private tour operators. As most Pakistanis are not eligible for the special quotas and the private operators are typically more expensive, the lottery is the primary source of visas for most Pakistanis. 134,948 people were part of the government lottery with $59 \%$ successful. ${ }^{4}$

The Hajj lottery is conducted over parties of up to 20 individuals who will travel and stay together during the pilgrimage. ${ }^{5}$ Parties are formed either voluntarily, often along family lines, or by staff of the bank branches. Parties are assigned into separate strata for the two main Islamic sects (Sunni/Shia), eight regional cities of departure, and two types of accommodation that vary slightly in housing quality. A computer algorithm selects parties randomly from each stratum until the quota of individuals for that stratum is full. This process leads to a slightly lower chance of success for larger parties; if the selected party is larger than the remaining quota, it is set aside and another is randomly chosen from the remaining pool.

The lottery selection algorithm was designed and implemented by an independent and reputable third party and there were no reports of lottery manipulation. The rich and connected typically go through a private Hajj tour operator or the special quota rather than participating in the Hajj lottery. Consistent with the hypothesis of random assignment, success in the Hajj lottery is individually and

\footnotetext{
${ }^{3}$ See Clingingsmith, Khwaja, and Kremer (2008) for a fuller description.

${ }^{4}$ Excluding applicants automatically given visas because they applied unsuccessfully in the two preceding years.

${ }^{5}$ In our survey sample, $34 \%$ of applicants were in a party with fewer than 5 people (only $1 \%$ were in a party of 1 ), and

$70 \%$ were in a party with 10 or fewer people. The remaining 30\% were in groups of size 11 to 20 .
} 
jointly uncorrelated with applicant characteristics listed on the Hajj application forms, such as gender, marital status, year of birth, education, branch of application, and whether applicants listed a telephone number. A joint F-test fails to reject the null hypothesis of random assignment with a pvalue of 0.98 (Table 1, Panel A). With observations on 134,948 Hajj applicants, if the lottery were subject to influence, one would have expected significant differences by characteristics such as education level, so this offers a pretty strong test.

Among successful Hajj applicants we surveyed, 99\% went on the Hajj. Some unsuccessful lottery applicants secure a place with a private Hajj operator or through the special quota. Thus, $11 \%$ of those who were unsuccessful in the government lottery still performed the Hajj that year.

Since compliance with the lottery is not perfect, we use success in the lottery as an instrumental variable to estimate the effect of performing the Hajj. This yields the Local Average Treatment Effect (LATE) for those for whom the outcome of the lottery determines Hajj participation. Our estimation equation is:

$$
Y_{i}^{k}=\alpha^{k}+\beta^{k} H_{a j j_{i}}+\lambda_{c}+\varepsilon_{i}^{k}
$$

where $\mathrm{Hajj}_{i}$ is an indicator variable for whether individual $i$ performed the Hajj, $Y_{i}^{k}$ is the $\mathrm{k}^{\text {th }}$ outcome of interest, and Hajji is instrumented by the individual's lottery status. As long as success in the Hajj lottery only affects outcomes by inducing applicants to undertake the Hajj, this provides unbiased estimates of $\beta^{k}$. While we have no explicit way of ruling out a direct lottery effect, it seems unlikely since our survey period was 8 to 11 months after the lottery. Potential direct effects, such as disappointment in not receiving a visa, are likely to be short-lived, especially given that individuals reapply. Moreover, such an effect would likely have led unsuccessful individuals to report higher distress, while we will show evidence to the contrary.

Equation (1) also includes stratum-by-party size cell fixed effects $\lambda_{c}$, as the randomization was done within strata and there were slightly different chances of success depending on party size. However, because quotas for each departure city were proportional to the number of applications and the chance of success varied only slightly with party size, results are similar without the cell dummies. Standard errors are clustered at the party level, since outcomes for people traveling together may not be independent.

Both for ease of exposition and to lessen data-mining concerns, we present our results using thematic indices that are constructed by grouping related questions. For example, for views on female education we construct an index that combines questions as about whether girls should receive education, what level of schooling girls should receive, etc. While results on any component 
question could potentially be due to chance (Type I error), this is less likely when one simultaneously considers several related questions in an index. Moreover, the use of indices reduces the risk of low statistical power (Type II error). We compute the average effect size (AES) across outcomes (components) within an index following O'Brien (1984) and Kling et al. (2004). ${ }^{6}$ For a family of J related outcomes $Y^{j}$ in an index, with Hajj local average treatment effects $\pi_{\mathrm{j}}$, the average effect size is $\tau=\frac{1}{J} \sum_{j=1}^{J} \frac{\pi_{j}}{\sigma_{j}}$, where $\sigma_{j}$ is the standard deviation of outcome $\mathrm{j}$ in the comparison group. ${ }^{7}$

We report standard tests of the null hypothesis of no effect for each individual index. However, since we have 25 indices, we also show our results are robust to multiple hypothesis testing by using a conservative Bonferroni-Holm test, which makes no assumptions about the correlation of hypotheses. We can reject the null hypothesis of one or more false positives with an $\alpha$ of 0.07 . Less conservative methods, such as specifying an acceptable false discovery rate, would make this result even stronger.

\section{The Survey}

We surveyed successful and unsuccessful applicants to the 2006 Hajj lottery five to eight months after the Hajj. ${ }^{8}$ The survey includes questions on religious knowledge and practice, tolerance, views on gender, social interaction and roles, political involvement and beliefs, physical and mental health, and business and employment, as well as background information on the household and its members.

The initial sampling frame was the list of all Hajj lottery applicants obtained from the Ministry. The survey area was limited for logistical ease to nine administrative districts in the Punjab province. ${ }^{9}$ Surveyors used addresses and telephone numbers provided in the applications to locate applicants and interview them at their residence. The sample was also restricted to Sunni applicants, because there were too few Shia applicants to draw meaningful inferences. To maximize statistical power, we randomly selected equal numbers of winning and losing parties. Within each party, we randomly

\footnotetext{
${ }^{6}$ Results are similar with indices that average over component questions (see the working paper version of paper).

${ }^{7}$ To test for $\tau$ against the null hypothesis of no average effect, we account for the covariance between the effects $\pi_{j}$ by jointly estimating the $\pi_{\mathrm{j}}$ in a seemingly unrelated regression framework. We stack the $J$ outcomes and use our treatment effects regression fully interacted with dummy variables for each outcome as the right-hand side. The coefficients $\pi_{j}$ are the same as those estimated in the outcome-by-outcome regressions. Our stacked regression now gives us the correct covariance matrix to form a test of $\tau$.

${ }^{8}$ Conducting a baseline survey was infeasible since the lottery took place less than a month after applicant data were available. Surveys after the lottery would not constitute a valid baseline because the successful applicants are preparing to leave and differentially affected.

9 The districts were Attock, Islamabad, Rawalpindi, Jhelum, Chakwal, Faisalabad, Sargodha, Multan, and Gujrat.
} 
selected an individual to interview, and, if other party members of opposite gender were identified as living with the individual, we also selected a second person of the opposite gender.

Surveyed applicants are broadly representative of the adult Pakistan population (Table 2) with some truncation of the extremes of the socioeconomic distribution, since the poorest cannot afford to go on the Hajj and the rich typically travel on private schemes. Hajj applicants have similar average education and household expenditures to the general population, but are older and more likely to be married. Forty percent are from cities, fairly similar to that in the general population.

Surveyors completed interviews with 1605 applicants, 63\% of the 2,537 they attempted to interview (Table 3, Panel A). However, only 7.9\% of the attempted interviews were refused. In about threequarters of unsuccessful attempts, surveyors were unable to contact or locate applicants. Some applicants lived in a different (out of sample) district from the one provided in their application address (often a relative's address they wished to travel with), and it was not logistically possible to survey them. In other cases, addresses were incomplete or incorrect or the applicant was not at home despite three separate attempts. Among applicants the survey team could contact (i.e. interviewed plus refusals), the survey completion rate was therefore $88.8 \%$.

Successful applicants completed the survey at a $66.5 \%$ rate, higher than the $60.0 \%$ rate for unsuccessful applicants. This difference is statistically significant at the 1\% level (Table 3, Panel A). Hajjis were easier to locate, perhaps because their participation in the Hajj made them better known in their locality. Successful applicants also had a slightly lower refusal rate possibly because they may have regarded the survey as being more pertinent for those who had actually performed the Hajj.

The unbalanced interview completion between successful and unsuccessful lottery applicants could potentially introduce selection and bias our estimate of the Hajj effect. ${ }^{10}$ Therefore, we provide three robustness checks against selection concerns. First, Table 1 Panel B shows that for completed interviews, lottery success is not individually or jointly correlated with observable applicant characteristics. Second, our results are robust to demographic controls. None of our 25 index

\footnotetext{
${ }^{10}$ A selection effect would imply the marginal surveyed successful applicant is less willing to give an interview (more uncooperative) and harder to locate. This is because the initial randomization guarantees successful and unsuccessful applicants are distributed identically along any attribute. If selection is introduced by, for example, successful applicants gaining incremental visibility from traveling, then the marginal successful applicant found is slightly less well known $e x$ ante than the marginal unsuccessful applicant found. However, it is not clear how such potential selection could generate several of our results, such as a shift from localized to global practice or increased tolerance. If anything one may expect the opposite for the tolerance result, since selection implies the interviewed successful applicant is marginally less cooperative.
} 
results qualitatively change with controls for district, urban or peri-urban location, and individual characteristics. $^{11}$

Finally, we examine the robustness of our results to a restricted subsample (Table 2) that excludes nine out of the 49 tehsils (sub-districts) in our survey area that were particularly difficult to survey. This subsample is balanced on survey completion and reasons for non-completion. It excludes tehsils with more than 25 selected applicants (tehsils with smaller samples may generate imbalance mechanically) where the completion rate for successful applicants exceeded unsuccessful ones by more than $7 \%$. This subsample contains $81 \%$ of the total interviews. While the completion rate was still somewhat higher for successful applicants $(65.8 \%$ vs. $64.0 \%)$, we fail to reject the null hypothesis of an identical completion rate with a p-value of 0.66 . As in the full sample, lottery success in the interviewed sub-sample is uncorrelated with applicant characteristics (Table 1, Panel B). As our results below show, there is no qualitative change in our estimates in the sub-sample.

\section{Main Results}

This section presents our main results on the impact of the Hajj. Subsections A-D examine religious behavior and practices, tolerance, gender attitudes, and well-being, respectively. Our power to detect interaction effects is limited, so we generally do not present interaction results, except in cases where we have strong priors and reasonable power and consistency, as in the case of gender. Our estimates capture the effect of the Hajj five to eight months after pilgrims return. While this limits our ability to explore persistence of the effects, we do not find any significant changes over the survey period.

The rows of Tables 4-8 present the average effect size (AES) estimates for each index, including the control and restricted subsample specifications. Since the results are very similar, we focus on the base specification. The component questions in each index are described in the notes to the tables. Table 9 further presents results for several index component questions of individual interest. A supplemental online appendix presents the Hajj impact estimates and definition details for all the component questions.

\section{A. Religious practices and beliefs}

Hajjis are 13\% more likely to report they are regarded as a religious person, a one-quarter standard deviation increase relative to the control group (Table 4, row 1).

\footnotetext{
11 We can use additional data such as assets and expenditure from survey data and the results are robust to these as well. We prefer not to present these as primary controls due to their potential endogeneity.
} 
Three indices explore how the Hajj affects religious practice and belief. The first measures global Islamic religious practice, meaning the performance of rites universally acknowledged within the Muslim world. Questions, described in the notes to Table 4, include the applicant's observance of prayer, fasting, and Qu'ranic recitation, etc. The Hajj increases the global religious practice index by 0.16 standard deviations (row 2). This is a fairly large effect, particularly since it reflects practice five to eight months post-Hajj, and not the fervor of a recently returned pilgrim. The Hajj nearly doubled the rate of regularly fasting outside of Ramadan (the obligatory month of fasting) to around 9\% and increased praying Tahajjud (supererogatory) prayers by two-thirds (Table 9, rows 2-3).

In most Muslim countries, there are a variety of Islamic traditions that are not as universally accepted as the global practices examined above. Some of these are specific to particular countries or regions. The Hajj rituals highlight global practices. Localized practices might decline because they compete for time and attention with global practices, or because the Hajj induces a shift in belief.

We find evidence of an absolute shift away from localized beliefs and practices. While most pilgrims initially have moderately high levels of localized beliefs, the Hajj leads to a 0.10 standard deviations reduction in an index of localized beliefs that are fairly common in South Asia but not among Muslims globally (Table 4, row 3). Some beliefs, such as visiting the tombs of saints and using amulets, have roots in local Sufi traditions. Others reflect local interpretation of Islamic doctrine, such as giving dowry (Islam instead emphasizes mehr, where a man commits to pay his wife in case of divorce) and what remarriage priority should be accorded to widows. While South Asian women often lose status when their husbands die and have little prospect of remarriage, in Islam a widow can readily remarry after a short waiting period.

The Hajj similarly reduces an index of localized religious practice, related mainly to the Sufi traditions mentioned above, by 0.10 standard deviations (Table 4, row 4). As we noted earlier, some have expressed concern about the erosion of local South Asian traditions. We later present evidence suggesting the Hajj does not produce a shift in favor of a Saudi version of Islam but rather a move towards the global mainstream.

\section{B. Tolerance}

We find that Hajjis display more positive views towards other nationalities and social groups, greater tolerance, and are more peacefully inclined (Table 5).

The Hajj increases an index of positive views about people from other countries by 0.15 standard deviations or more than 33\% (Table 5, row 1). Haj)is update their beliefs most positively about 
nationalities they are likely to interact with frequently. The largest positive impact ( 0.32 standard deviations) is on views towards Indonesians (Table 9, row 4), the largest non-Saudi pilgrim group and the one Hajjis report as observing the most. Hajjis also have a 0.14 standard deviations more positive view of Saudis (Table 9, row 5). There is no effect on views of Europeans. Hajjis are also significantly more likely to declare that Indonesians are the best practitioners of Islam (regression not reported). In follow-up open-ended interviews, Pakistani Hajjis also reported positive interactions with Indonesians. For example, one older female Hajji said, "I had a very good experience with female Hajjis from Indonesia. They would make space for me whenever I was walking if I gestured for them to do so. One of them even gave me Vicks VapoRub when she found out that I had the flu."

The Hajj also increases an index of beliefs that adherents of different sects, ethnicities, and religions are equal by 0.13 standard deviations (Table 5 , row 2 ). In contrast to the views on different nationalities, the largest move towards equal status is for people of a different religion (Table 9, row 6), who would not be encountered during the Hajj as they aren't permitted to attend. Hajjis may thus be willing to extend their notions of tolerance beyond the Muslim world.

Similarly, the Hajj increases an inter-group harmony index by 0.13 standard deviations (Table 5 , row 3). The index solicits applicants' views on whether people from different ethnic groups, Islamic sects, and religions could live together in harmony in the same society. It also includes a practicebased question about how frequently the respondent prays in a mosque of a different school of thought. The effect is largest for religion, about which the control group has the lowest belief regarding harmony (Table 9, row 7). The effect on the respondent praying in a mosque of a different school of thought is also large, almost doubling the control group mean of $4.9 \%$ (Table 9, row 8).

We complement the harmony index by exploring the extent to which the Hajj leads to greater inclination towards peace. The Hajj increases a peaceful inclination index by 0.11 standard deviations (Table 5, row 4). Examining some of the component questions, we find that the Hajj almost doubles the number of respondents who declare that Osama bin Laden's goals are incorrect from $6.8 \%$ to $13.1 \%$ and increases the fraction declaring his methods incorrect from 16\% to 21\% (Table 9, rows 9-10). ${ }^{12}$ The Hajj increases the belief that peace with India is important from $91 \%$ to $96 \%$ (Table 9, row 11). Hajjis are also $17 \%$ more likely to say it is never correct to physically punish someone who has dishonored the family (Table 9, row 12). While these results are consistent with becoming more tolerant, it is also possible that the Hajj confers a religious legitimacy to individuals that allows them to more willingly express previously held views.

12 Slightly more than half say his goals are correct; one-third say his methods are correct; quite a few do not answer. 
One might suspect that more orthodox religious practice could be associated with support for political Islam, which advocates a closer relationship between religion and politics and which is often associated with negative perceptions of the West. We see no increase in belief in either the role of religion in politics or in more negative views of the West. It is nonetheless possible that increased tolerance tempers such desires and perceptions, if they do in fact go along with increased orthodoxy. The Hajj reduces support for political Islam, although the effect is only weakly significant at 15\% (Table 5, row 5). The political Islam index includes questions on how deeply religion should be involved in politics. While the average respondent is likely to see a role for religion in matters of the state, Hajjis are no more likely to do so in spite of an increased attachment to global Islam. In fact, the Hajj significantly reduces beliefs that the state should enforce religious injunctions and that religious leaders should be able to dispense justice on their own. The Hajj does not lead to any increase in an index of negative attitudes toward the West (Table 5, row 6) that encompasses views on adopting Western social values and technologies, and commonly held suspicions towards the West. We can reject a negative effect of one-twentieth of a standard deviation with $95 \%$ confidence.

We find no evidence that the Hajj affects the tails of the distribution of attitudes towards political Islam and views towards the West. Moreover, while young people may potentially be more susceptible to intolerance, the six tolerance indices examined don't show any differential Hajj effect for younger pilgrims (regressions not reported). If anything, the harmony index shows a more positive effect for the young.

\section{The Hajj and Gender}

We noted earlier that the Hajj may provide Pakistani pilgrims a novel opportunity in which men and women interact, perform rituals as equals, and observe the gender roles of other nationalities. Perhaps on account of this, we find that the Hajj causes a 0.12 standard deviation increase in an index of questions about the status of women relative to men along intellectual, spiritual, and moral dimensions (Table 6, row 1). The effect is largest on the spiritual dimension with an increase of over $50 \%$ (from 11\% to 17\%) in believing that women are better (Table 9, row 13). Hajjis are also more likely to believe that, while there are gender differences, women's overall status is equal.

The Hajj also increases an index that captures awareness of women's quality of life issues in Pakistan by 0.16 standard deviations (Table 6 , row 2). The index includes respondents' rating of women's quality of life in other countries relative to Pakistan. The largest effect is on the relative quality of life of Indonesian/Malaysian women being higher, paralleling the previous results on views of other nationalities (Table 9, row 14). Interestingly, Hajjis show a larger increase in their views on the relative quality of life of women in the West compared to Saudi Arabia (Table 9, rows 15-16). In 
addition, Hajjis are also more likely to think that crimes against women are high, both on an absolute scale and relative to crimes against men (Table 9, rows 17-18).

Do the more favorable assessment of women's qualities and the greater concern regarding their quality of life in Pakistan go along with a changed view of the role women ought to take in society? We construct three indices to explore the areas of girls' education, women's workforce participation and choice of professions, and the willingness to challenge the authority of men relative to women within the household and in social contexts (Table 6, rows 3-5).

The Hajj increases favorable views toward education for girls by about 0.09 standard deviations (Table 6, row 3). We find positive Hajj effects on all components except equal educational attainment across gender. The Hajj increases the desire that girls attend school from $93 \%$ to $96 \%$ (Table 9, row 19). Hajjis are $8 \%$ more willing to allow both their boys and girls to attend coeducational schools at all levels (Table 9, rows 20-21).

Further, the Hajj increases an index of questions about women's workforce participation and profession choice by 0.12 standard deviations (Table 6, row 4). The Hajj has a substantial impact on each index component. For example, the Hajj increases the fraction desiring their daughters/granddaughters work from $54 \%$ to $60 \%$ (Table 9 , row 22). Hajjis are also $12 \%$ more likely to think it is important that their future daughter-in-law be employed (Table 9, row 23).

However, Hajjis' more favorable views of women do not extend to challenging male authority in the household (Table 6, row 5). The Hajj has little or no impact on an index that includes questions regarding whether the respondent challenges traditional attitudes on women's roles in domestic matters, such as fertility decisions and marrying against parental wishes, and unequal Islamic rules on gender, such as those related to inheritance laws and providing financial witness. This is perhaps unsurprising given the greater authority and responsibility typically accorded to men along several dimensions within Islam.

Nevertheless, the changed perceptions about gender roles do seem to accompany changes in household behavior. The Hajj increased the fraction reporting occasional marital disagreements by 10 percentage points, a large increase relative to the comparison mean of 15\% (regression not reported). Since most married couples perform the Hajj together, it is not possible to separate this effect by the respondent's gender (since it reflects both their own and their spouse's Hajj impact).

While sample size limitations do not readily allow us to examine heterogeneity of the impact of the Hajj, nevertheless we find that only the girls' education index shows a smaller increase for men than 
women, who in any case already have close to $100 \%$ agreement with the view that girls should be educated (regressions not reported). In fact, the Hajj leads to somewhat larger changes in the indices of views on women and quality of life for male Hajjis than for female ones.

\section{Well-Being}

Hajjis, primarily women, are more likely to report negative feelings that suggest distress, and are less likely to report positive feelings of well-being (Table 7, rows 1-2 and 5-6). This could potentially be due to the changes in Hajjis' beliefs and frame of reference discussed above (which the psychology literature suggests can lead to stress), to financial stress associated with the cost of the Hajj, or to the impact of the Hajj on physical health.

Hajjis report somewhat higher distress, as measured by a version of the K6 screening scale (Kessler et al., 2003). ${ }^{13}$ The index aggregates respondents' experience of six negative feelings in the past month, which we rescale so that a higher value represents less distress. While applicants had a low level of underlying distress, the Hajj reduces the index by 0.21 standard deviations (Table 7, row 1). The Hajj also reduces an index of five positive feelings by 0.11 standard deviations (row 2). In the restricted subsample, the Hajj effect drops slightly to 0.08 standard deviations with a marginal significance of $11 \%$.

The increase in distress falls entirely on women (Table 7, rows 5-6). On both the rescaled K6 index and the positive feelings index, there is no significant effect of the Hajj on men. Increased distress might be due to the stark contrast between the typical Pakistani woman's daily life and the relatively greater equality and integration experienced during the Hajj. The impact of the Hajj on gender attitudes suggests an increased realization that the constraints and restrictions women are accustomed to in Pakistan may not be part of global Islam. A literature in psychology (Crosby, 1991; Lantz, et al., 2005) suggests that such changes in frame of reference can induce significant stress, although eventually such stress helps deal with the change.

While the Hajj has a negative impact on a female pilgrim's emotional state, it does not affect overall life satisfaction, either on average, or for women (rows 3 and 7). We can reject a negative effect on the index of life satisfaction of about one-tenth standard deviation with $95 \%$ confidence. While we cannot rule it out, we do not see much evidence for the hypothesis that the substantial financial expenditure required by the Hajj creates financial stress that accounts for Hajjis' negative feelings. In fact we can reject the hypothesis that the Hajj has a negative effect of more than one twelfth of a

\footnotetext{
${ }^{13}$ We should caution that, to our knowledge, the K6 index has not been formally validated for Pakistan.
} 
standard deviation on the individual component question about satisfaction with finances. The Hajj also does not affect monthly household consumption expenditures or a measure of household assets (regressions not reported). Our interviews reveal that most do not consider the pool of savings for the Hajj as fungible; those unable to go keep these Hajj funds in order to reapply in the future.

The Hajj leads to a 0.21 standard deviations reduction in an index of physical health (Table 7, row 4) that includes self-reported physical health and illness/injury. While the decrease in self-perceived health could be due to a change in the reference group for Hajjis from local people to those encountered from other countries on the Hajj, it is not clear that this could account for the doubling in reports of serious physical injury or illness.

The negative physical health effects are also stronger for women (row 8), suggesting that part of the negative effect of the Hajj on women's feelings of well-being could be explained by poorer physical health. ${ }^{14}$ However, the negative point estimates on men's physical health are larger than the effect on the K6 index (0.11 vs. 0.04 standard deviations) suggesting the two do not exactly co-move. Also, the coefficient on Hajj lottery success in a regression predicting the K6 index is similar whether or not one controls for physical health, providing further suggestive evidence that the channel for Hajj effects on emotional health is not simply through physical health.

\section{Potential Channels}

While our methodology does not provide experimental variation that isolates the potential channels through which the Hajj may impact the pilgrim, we can offer some suggestive evidence. We consider both external channels, which operate by changing the environment a Hajji faces upon return, and internal channels, which reflect changes in Hajjis' beliefs and preferences. We argue the evidence points towards the importance of the internal channel and, within that, to exposure to people of differing nationalities, sects, and gender.

\section{A. External Social Environment}

Historical accounts suggest the Hajj confers social prestige and legitimacy (Donnan, 1989; Yamba, 1995; Eickelman and Piscatori, 1990), although some anecdotal evidence suggests that contemporary Hajjis no longer experience this increase in social status (Scupin 1982). A changed social role may bring expectations for the changed behavior and beliefs that are reflected in our results. For

\footnotetext{
${ }^{14}$ Negative physical health effects are not larger for older people.
} 
example, Hajjis may be expected to be more religious, and may practice more to fulfill that expectation. Alternatively, increased religious legitimacy may allow Hajjis to express longstanding opinions they have not expressed before, such as those opposing Osama Bin Laden.

We find no impact of the Hajj on an index of social status and engagement (Table 8, row 1). The 15 components include the frequency of social visits, the giving of advice, and membership in social organizations. ${ }^{15}$ We might further expect social standing to be reflected in awareness of and engagement in political affairs. In fact we find no impact of the Hajj on a political engagement index (Table 8, row 2) that asks about voting, interest in national affairs, political opinion, and membership in political organizations.

It's possible that the Hajj once led to a much greater change in social roles than it does currently, and that the increased rate of participation in the Hajj due to lower travel costs has reduced the social prestige associated with completing the Hajj. In any case, it does not seem likely that changes in the social role upon return can account for the findings in the previous sections.

\section{B. Internal State}

The Hajj may alter an individual's internal state, changing beliefs and preferences. For example, Hajjis may undergo a change in religious commitment during the pilgrimage that increases orthodoxy in religious practice and leads them to greater tolerance and belief in gender equity consistent with the Qu'ran. Alternatively, Hajjis' increased tolerance and changed gender attitudes may reflect their new exposure to people from different countries and sects, and to members of the opposite gender outside their family. While we cannot rule out the religious dimension, we interpret the evidence as pointing more towards the increased exposure to Muslims from around the world.

We find that the Hajj does not increase an index of formal religious knowledge (Table 8, Row 3), but does increase indices of experiential knowledge about diversity of opinion within Islam, gender within Islam, and the world more broadly (Table 8, Rows 4-6). The changes in experiential knowledge point to the importance of interaction with and observation of other groups. ${ }^{16}$ Furthermore, to the extent that a spiritual transformation and change in religious commitment

\footnotetext{
15 All except two component questions are not significant even at the $20 \%$ level (Appendix 5). These two show that Hajjis are slightly more likely to have visitors from out of town, and slightly more likely to be self-employed (p-values of 0.14 each). However, the magnitudes of these effects are small (5\% and $3 \%)$.

${ }_{16}$ While some of our results could be due to a generic effect of traveling to a different country rather than the experience of the Hajj, it seems unlikely this accounts for all of the results. For example, it is hard to see why a pure travel effect would lead to more positive beliefs about Indonesians.
} 
would be accompanied by a desire to acquire greater religious knowledge, these results do not suggest that such a change is a primary driver of the findings.

The Hajj increases the index measuring knowledge of diversity within Islam by 0.15 standard deviations (Table 8, Row 4). Index components include questions on how schools of Sunni thought differ, such as whether it is necessary to wear a prayer cap. The index of gender knowledge and awareness, that combines eight questions on gender and marriage in Islam and on having an opinion on women's issues, increases by 0.13 standard deviations (Table 8, Row 5). ${ }^{17}$ Similarly, Hajjis also show an increase of 0.08 standard deviations in the global knowledge index that reflects general awareness of the world outside Pakistan (Table 8, Row 6). ${ }^{18}$

Pilgrims who travel in smaller parties, and thus have more opportunity to interact with nonPakistanis, experience larger gains in the diversity, gender, and global knowledge indices, as well as in positive views of people from other countries. This is consistent with the idea that the exposure channel is important. The coefficients on the interaction between the Hajj and small party size are large and significant at conventional levels for the gender and global knowledge indices and for positive views of other countries. The small-party interaction effects are $0.13,0.14$, and 0.14 standard deviations, respectively, with p-values of $0.07,0.10$, and 0.06 . Point estimates for the group size interaction on other tolerance indices also point to a similar story. The interactions are robust to including other demographic controls and their interactions. However, we cannot rule out that unobservable differences between parties of different size are driving the interaction effects.

We would expect Hajj effects to also be larger for those with less prior exposure to situations similar to the Hajj. However, very few respondents had previously traveled outside Pakistan, which limits our power to test this interaction. There are a few robust interactions with literacy and urban residence, though it is unclear these relate to the prior exposure that is relevant. While urban applicants do show a smaller decrease in localized beliefs and practices, the literate see larger gains in some of the experiential knowledge measures, suggesting that literacy may partly be picking up other factors such as ability to interact with others. Since party size is often assigned by banks, and is thus less likely to be correlated with unobserved factors, we prefer focusing on it as a test of exposure.

\footnotetext{
${ }^{17}$ Four of the eight questions in the gender knowledge and awareness index are about awareness rather than knowledge: whether the respondent has heard of the Islamic law against adultery and whether they have an opinion on women's lives in three different countries. The Hajj has a somewhat smaller, but still significant, effect on a pure gender knowledge index that is constructed without these questions.

${ }^{18}$ We should note that this latter effect falls slightly to 0.07 standard deviations and is marginally significant at $12 \%$ in the restricted subsample.
} 
While Hajjis are also exposed to Saudi Arabia and its people, we think this is unlikely to drive our observed effects. Only the move away from localized religious practices seems consistent with a Saudi influence. Saudi Arabia is generally less accepting of other schools of thought and enforces strict gender segregation; Hajj impacts on gender views are more in line with the more liberal attitudes in other Muslim countries. ${ }^{19}$

Our results thus suggest that Hajjis are likely to be influenced by the practices and beliefs of the typical pilgrim that they encounter during the Hajj, with possibly greater salience to those groups that are more visibly different or are regarded as better in some way, such as in their behavior or organization (factors often mentioned in our interviews). Exposure may therefore induce convergence of belief to the Islamic mean. To the extent that this convergence is a significant force, some of our results may differ for pilgrims from other countries.

\section{Conclusion}

Our findings show that the Hajj induces a shift from localized beliefs and practices towards global Islamic practice, increases tolerance and peaceful inclinations, and leads to more favorable attitudes toward women. This demonstrates that deep-rooted attitudes such as religious beliefs and views about others can be changed and also challenges the view that Islamic orthdoxy and extremism are necessarily linked. We conclude with some tentative implications of our results on how social institutions help shape individual beliefs and identity and, at a macro-level, how they may foster unity within belief systems.

The social psychology literature suggests that social interactions can either lead to positive or negative feelings towards other groups depending on whether the setting is competitive or cooperative. Several features of the Hajj may create a setting in which the interaction among different groups helps build common purpose and identity. It's worth noting that other social institutions also share such features with the Hajj. Consider medical education, police/military basic training, and international peace camps. Like the Hajj, participants in these institutions leave their everyday environments and their restrictions on mixing across certain lines, such as ethnicity and social class, to enter a setting in which they collectively perform similar actions, often physically strenuous ones, which require cooperation from others. Furthermore, participants in all these

\footnotetext{
${ }^{19}$ A comparison of gender views across questions from the World Values Surveys shows that Saudis indeed have more conservative gender views than Pakistanis, while Pakistanis in turn are more conservative than Indonesians. 62\% of Saudis believe a university education is more important for men than women, compared to 24\% Pakistanis and $17 \%$ Indonesians. Similarly, 34\% of Saudis do not think that both husband and wife should contribute to household income, compared to $30 \%$ Pakistanis and $15 \%$ of Indonesians.
} 
institutions accentuate their similarity, often by taking on common dress or hairstyle during the experience and a common title afterwards.

It also seems likely that the religious element of the Hajj plays a role beyond providing a cooperative setting. For example, Hajjis' changed attitudes on gender appear to be circumscribed by those norms broadly accepted in Islam. Further, it is plausible that the religious context provides the legitimacy that makes it acceptable for adherents to alter their views. If a Pakistani woman observes her Indonesian counterpart engaging equally with her spouse without comprising her piety, she may also consider it permissible to do so. If pilgrims see others praying somewhat differently yet without interference in the holiest of Muslim places, they may reason that some degree of religious diversity is acceptable.

Our results also shed light on why religions often mandate practices that are costly for individual adherents. While club good models that apply the framework of individual rationality, as in Iannaccone (1992) and Berman (2000), deliver compelling explanations, additional insights can be obtained using an evolutionary framework in which institutions and prescriptions that reinforce and propagate the religion's beliefs and practices are more likely to persist. By moving pilgrims toward the religious mainstream, the Hajj may help Islam overcome an evolutionary hurdle faced by world religions: maintaining unity in the face of the divergence of practices and beliefs through local adaptations. A number of religious institutions, including written holy texts and central authorities, can help overcome this hurdle. Sunni Islam lacks a central authority, and so the role of pilgrimage may be particularly important.

However, achieving convergence and maintaining unity likely requires that there be limits to how much diversity is allowed. Too diverse a group may make it difficult to find common ground and too much variance in beliefs increases the likelihood that undesirable religious innovations spread. It is therefore noteworthy that while people of different faiths made the pilgrimage to Mecca in preIslamic times (Armstrong 1997), its institutionalization with Islam's emergence was accompanied by restricting it to Muslims and disallowing non-Islamic practices that were once elements of the pilgrimage.

Both the evolutionary and club good perspectives imply that religions with practices that generate positive externalities for other adherents, provided these are socially efficient, are more likely to persist by raising the attractiveness of being an adherent. Historically, undertaking the Hajj may have created positive externalities for other Muslims both through its effect on tolerance, and by facilitating economic trade and the diffusion of economic, cultural, and scientific ideas (Bose, 2006). While we find little evidence of individual medium-term gains in socioeconomic status and 
engagement in our sample, there is clear evidence for a positive externality in the increased tolerance towards others. Of course, given the significant financial and health costs entailed in undertaking the Hajj, individuals still need to be induced to participate. However, this can be done through religious injunctions, sanctions, and rewards. The Hajj is one of the five pillars of Islam and there is the belief that performing it sincerely cleanses one of all sins.

Models of costly religious practices also often argue that these practices signal commitment and screen out those who may free ride on the religious community. Since individuals have already signaled such commitment by applying to the Hajj (less than one percent withdraw), our comparisons between applicants are not influenced by signaling effects. Our results therefore indeed capture a treatment effect. The fact that Hajj has a direct treatment effect is not surprising, since one would expect that were it only serving a signaling function, it would decline in observance relative to alternate practices that could screen just as well but at a lower cost.

The findings in this paper also pose the question of whether pilgrimages or central gatherings may foster such unity in other beliefs systems, religious or otherwise, and conversely, whether their absence increases susceptibility to schisms. The Kumbh Mela, bringing together millions of Hindus every three years, along with Catholic pilgrimages to Lourdes and Rome, may play such a cohesive role. Non-religious examples include national political conventions in the United States that may promote party unity and exchange among delegates from different regions. Conversely, the split between Judaism and Christianity occurred shortly after the destruction by the Romans of the Jewish temple in Jerusalem, which was a central gathering place, in the year 70 A.D. One may even conjecture whether the multiplication of Protestant sects would have been muted had there been a central holy site for pilgrimage among Protestants.

Further insights are likely to come from investigating the impact of the Hajj over different durations, on pilgrims from other countries that differ from Pakistan in their attitudes and exposure, and the impact of other pilgrimages. Since several other countries also allocate Hajj visas by lottery, it should be possible to use the same methodology. More generally, one could use similar approaches to examine the impact of other institutions on social identity. For example, one could use draft lotteries (Angrist, 1990) to examine the impact of military service on social identity or regression discontinuity designs to examine the impact of professional training on beliefs and attitudes. Building up evidence from a series of such studies would shed additional light on the broader roles played by institutions, religious and non-religious, in the shaping of beliefs and identity and the evolution of ideologies and belief systems. 


\section{Bibliography}

Ahmed, Q.A., Y.M. Arabi, and Z.A. Memish. 2006. Health Risks at the Hajj. The Lancet 367: 10081015.

Angrist, Joshua. 1990. Lifetime Earnings and the Vietnam Era Draft Lottery: Evidence from Social Security Administrative Records. American Economic Review, 80(3): 313-336.

Armstrong, K. 1997. Jerusalem: One City, Three Faiths. New York: Ballantine Books.

Aronson, E. and Patnoe. S. 1997. The Jigsaw Classroom. New York: Longman.

Azarya, V. 1978. Aristocrats Facing Change: The Fulbe in Guinea, Nigeria, and Cameroon. Chicago: University of Chicago Press.

Barro, Robert, and McCleary, R.M. 2003. Religion and Economic Growth across Countries. American Sociological Review 68(5): 760-781.

Berman, Eli. 2000. Sect, Subsidy, and Sacrifice: An Economist's View of Ultra-orthodox Jews. Quarterly Journal of Economics, 115(3): 905-953.

Bianchi, R. 2004. Guests of God: Pilgrimage and Politics in the Islamic World. Oxford: Oxford University Press.

Boisjoly, J., G. Duncan, M. Kremer, D. Levy, and J. Eccles. 2006. "Empathy or Antipathy? The Consequences of Racially and Socially Diverse Peers on Attitudes and Behaviors." American Economic Review 96(5): 1890-1906.

Bose, Sugata. 2006. A Hundred Horizons: the Indian Ocean in the Age of Global Empire. Cambridge: Harvard University Press.

Clingingsmith, David, Asim Ijaz Khwaja, and Michael Kremer. 2008. "Estimating the Impact of the Hajj: Religion and Tolerance in Islam’s Global Gathering." KSG Working Paper RWP08-22.

Crosby, F. 1991. Juggling: The Unexpected Advantages of Balancing Career and Home for Women and their Families. New York: Free Press.

DeVries, D.L., and R.E. Slavin. 1978. "Teams-Games-Tournaments (TGT): Review of Ten Classroom Experiments." Journal of Research and Development in Education 12: 28-38.

Donnan, Hastings. 1989. "Symbol and Status: The Significance of the Hajj in Pakistan." Muslim World 79(3-4): 205-216.

Eickelman, Dale F., and James Piscatori. 1990. "Muslim Travellers: Pilgrimage, Migration, and the Religious Imagination.” In Barbara D. Metcalf, ed. Comparative Studies on Muslim Societies, Vol. 9. Berkeley: University of California Press.

Fisman, Raymond, S. Iyengar, E. Kamenica, and Itamar Simonson. 2008. "Racial Preferences in Dating." Review of Economic Studies 75(1), 117-132.

Glaeser, E. and S. Glendon (1998). "Incentives, Predestination and Free Will," Economic Inquiry, July, 429-443.

Guiso, Luigi, Sapienza, Paola, and Luigi Zingales. 2003. "People's Opium? Religion and Economic Attitudes." Journal of Monetary Economics, 50(1): 225-282..

Iannaccone, Laurence R. 1992. "Sacrifice and Stigma: Reducing Free-riding in Cults, Communes, and Other Collectives." Journal of Political Economy 100(2): 271-291.

Ibn Battuta, 2002 [ca. 1355]. Tuhfat al-Nuzzar fi Ghara'ib al-Amsar. Beirut: Dar al-Kutub al-'Ilmiyya.

Johnson, D.W., and R.T. Johnson. 1983. "The Socialization and Achievement Crisis: Are Cooperative Learning Experiences the Solution?" In L. Bickman, ed. Applied Social Psychology Annual, Vol. 4. Beverly Hills, CA: Sage.

Kessler, R.C., Barker, P.R., Colpe, L.J., Epstein, J.F., Gfroerer, J.C., Hiripi, E., Howes, M.J, Normand, S-L.T., Manderscheid, R.W., Walters, E.E., Zaslavsky, A.M. 2003. "Screening for 
Serious Mental Illness in the General Population.” Archives of General Psychiatry. 60(2): 184189.

Kling, J. R., J. B. Liebman, L. F. Katz, and L. Sanbonmatsu. 2004. "Moving to Opportunity and Tranquility: Neighborhood Effects on Adult Economic Self-Sufficiency and Health from a Randomized Housing Voucher Experiment," Princeton IRS Working Paper 481, April.

Lantz, P., House, J., Mero, R. Williams, D. 2005. "Stress, Life Events, and Socioeconomic Disparities in Health: Results from the Americans' Changing Lives Study." Journal of Health and Social Behavior 46(3): 274-288.

Low, Michael. 2007. Empire of the Hajj: Pilgrims, Plagues, and Pan-Islam under British Surveillance. Unpublished M.A. thesis.

McCleary, R.M. 2007. "Salvation, Damnation, and Economic Incentives." Journal of Contemporary Religion 22(1): 49-74.

Naipaul. V. S. 1981. Among the Believers: An Islamic Journey. New York: Vintage.

O'Brien, Peter C. 1984. "Procedures for Comparing Samples with Multiple Endpoints." Biometrics 40(4): 1079-1087.

Organization of Islamic Conference. 2007. Report on the Seventeenth Islamic Conference of Foreign Ministers: Resolutions on Legal, Information, and Political Affairs. http:/ /www.oicoci.org/english/conf/fm/ $17 / 17 \% 20$ icfm-political-en.htm.

Pettigrew, T.F. and Tropp, L.R. 2006. “A Meta-Analytic Test of Intergroup Contact Theory.” Journal of Personality and Social Psychology, 90(5): 751-783.

PEW Forum. 2007. "Public Expresses Mixed Views of Islam, Mormonism.” Pew Forum on Religion \& Public Life: http://pewforum.org/surveys/religionviews07/

Putnam, Robert. 2007. "American Grace: The Changing Role of Religion in America." Presentation, Fall 2007 Faculty Research Seminar. John F. Kennedy School of Government, Harvard University. September 26.

Sacerdote, B. and E.L. Glaeser. 2001. "Education and Religion." National Bureau of Economic Research Working Paper No. 8080.

Scupin, Raymond. 1982. "The Social Significance of the Hajj for Thai Muslims." Muslim World 72(1): 25-33.

Sherif, M., Harvey, O., White, B., Hood, W., and Carolyn Sherif. 1954. Intergroup Conflict and Cooperation: The Robber's Cave Experiment. Norman: University of Oklahoma Press.

Slavin, R. E. and R. Cooper. 1999. "Improving intergroup relations: Lessons learned from cooperative learning programs." Journal of Social Issues 55(4): 647-664

Stephan, W.G. 1978. "School Desegregation: An Evaluation of Predictions Made in Brown v. Board of Education." Psychological Bulletin 85: 217-38.

The Sunday Times “Terror Watch on Mecca Pilgrims," January 21.

Tajfel, H. 1970. "Experiments in Intergroup Discrimination." Scientific American 223: 96-102.

Tajfel, H. and Turner, J. C. (1986). “The Social Identity Theory of Inter-Group Behavior.” In S. Worchel and L. W. Austin, eds., Psychology of Intergroup Relations. Chicago: Nelson-Hall.

Wolfe, M. 1997. One Thousand Roads to Mecca: Ten Centuries of Travelers Writing about the Muslim Pilgrimage. Grove Press.

X, Malcolm with Alex Haley. 1965. The Autobiography of Malcolm X. New York: Grove Press. Yamba, C. 1995. Permanent Pilgrims: The Role of Pilgrimage in the Lives of West African Muslims in Sudan. Edinburgh: Edinburgh Univ. Press. 


\begin{tabular}{|c|c|c|c|c|c|c|}
\hline \multirow[b]{2}{*}{ Applicant Characteristic } & Success & Lottery & $\begin{array}{l}\text { Success } \\
\text { Among I }\end{array}$ & $\begin{array}{l}\text { Lottery } \\
\text { erviewed }\end{array}$ & $\begin{array}{l}\text { el B } \\
\text { Success } \\
\text { Among I } \\
\text { Restric } \\
\text { sat }\end{array}$ & $\begin{array}{l}\text { Lottery } \\
\text { erviewed, } \\
\text { d Sub- } \\
\text { le }\end{array}$ \\
\hline & Coef. & $\mathrm{SE}$ & Coef. & $\mathrm{SE}$ & Coef. & SE \\
\hline Female & -0.001 & $(0.004)$ & -0.017 & $(0.022)$ & -0.026 & $(0.024)$ \\
\hline Application Number ${ }^{A}$ & 0.001 & $(0.003)$ & -0.003 & $(0.015)$ & -0.015 & $(0.016)$ \\
\hline Travel Party Number ${ }^{\mathrm{A}}$ & 0.005 & $(0.006)$ & 0.071 & $(0.068)$ & 0.037 & $(0.072)$ \\
\hline Year of Birth & 0.000 & $(0.000)$ & 0.001 & $(0.001)$ & 0.001 & $(0.001)$ \\
\hline Married & 0.009 & $(0.008)$ & -0.017 & $(0.063)$ & 0.006 & $(0.073)$ \\
\hline Middle School & -0.001 & $(0.005)$ & -0.019 & $(0.037)$ & -0.012 & $(0.041)$ \\
\hline High School & 0.000 & $(0.006)$ & -0.045 & $(0.046)$ & -0.050 & $(0.051)$ \\
\hline Intercollege and Up & 0.002 & $(0.008)$ & -0.005 & $(0.052)$ & -0.006 & $(0.060)$ \\
\hline Branch of Application $^{\mathrm{A}}$ & 0.005 & $(0.009)$ & -0.004 & $(0.042)$ & 0.000 & $(0.000)$ \\
\hline Provided Phone Number & -0.001 & $(0.011)$ & 0.080 & $(0.060)$ & 0.094 & $(0.064)$ \\
\hline Constant & 1.142 & $(0.264)$ & -1.464 & $(2.499)$ & -2.481 & $(2.689)$ \\
\hline Observations & 134,948 & & 1,605 & & 1,295 & \\
\hline $\begin{array}{l}\text { R-squared } \\
\text { Joint F-Test of Individual }\end{array}$ & 0.02 & & 0.06 & & 0.10 & \\
\hline Characteristics ( $\mathrm{p}$-value) & 0.98 & & 0.89 & & 0.81 & \\
\hline
\end{tabular}

Notes: Robust standard errors in parentheses clustered at the party level: * significant at 10\%; ** significant at 5\%; *** significant at 1\%. Regressions include dummies for place of departure $\mathrm{X}$ accomodation category $\mathrm{X}$ party size category.

${ }^{A}$ Application number is in units of 100,000; travel party number is in units of 10,000; Branch code is in units of 1,000 .

Table 2: Summary Statistics

\begin{tabular}{|c|c|c|c|c|c|c|}
\hline & \multicolumn{2}{|c|}{$\begin{array}{l}\text { Adult Pakistani Population } \\
\text { (restricted }>20 \text { year old) }\end{array}$} & \multicolumn{2}{|c|}{ Full Sample } & \multicolumn{2}{|c|}{ Restricted Sub-sample } \\
\hline & Mean & Std. Dev. & Mean & Std. Dev. & Mean & Std. Dev. \\
\hline$\overline{\text { Age }}$ & 40.16 & 16.244 & 54.575 & 13.240 & 55.039 & 13.246 \\
\hline Female & 0.499 & 0.500 & 0.490 & 0.500 & 0.496 & 0.500 \\
\hline Married & 0.703 & 0.497 & 0.943 & 0.232 & 0.948 & 0.222 \\
\hline Illiterate & 0.482 & 0.458 & 0.402 & 0.490 & 0.417 & 0.493 \\
\hline Intercollege and Up & 0.201 & 0.43 & 0.178 & 0.383 & 0.157 & 0.364 \\
\hline City $^{\mathrm{A}}$ & & & 0.400 & 0.490 & 0.372 & 0.483 \\
\hline Periurban/large village ${ }^{\mathrm{A}}$ & & & 0.274 & 0.460 & 0.293 & 0.455 \\
\hline $\operatorname{Rural}^{\mathrm{A}}$ & & & 0.325 & 0.470 & 0.335 & 0.472 \\
\hline Ballot Success & & & 0.533 & 0.499 & 0.524 & 0.500 \\
\hline Monthly Expenditures (log) & 8.678 & 0.641 & 8.832 & 0.783 & 8.896 & 0.726 \\
\hline
\end{tabular}

Notes: $\mathrm{N}=1605$ for full sample, $\mathrm{N}=1295$ for subsample, and N=29,995 for Adult Pakistani Population. The Pakistani Adult population is from the MICS 2003-4 survey (restricted to the same districts as in our sample).

${ }^{\text {A }}$ City, periurban, and rural classifications comparable to our survey data are not available in the MICS. 
Table 3: Survey Completion Statistics

\begin{tabular}{|c|c|c|c|c|c|c|}
\hline & \multicolumn{3}{|c|}{ Panel A: Full Sample } & \multicolumn{3}{|c|}{ Panel B: Restricted Sub-sample } \\
\hline & \multirow[b]{2}{*}{ Total } & \multicolumn{2}{|c|}{ Lottery Status } & \multirow[b]{2}{*}{ Total } & \multicolumn{2}{|c|}{ Lottery Status } \\
\hline & & Successful & Unsuccessful & & Successful & Unsuccessful \\
\hline Selected for interview & 2537 & 1286 & 1251 & 1995 & 1032 & 963 \\
\hline Raw completed interviews & 1605 & 855 & 750 & 1295 & 679 & 616 \\
\hline Completion rate & $63.3 \%$ & $66.5 \%$ & $60.0 \%$ & $64.9 \%$ & $65.8 \%$ & $64.0 \%$ \\
\hline \multicolumn{7}{|l|}{ Not completed } \\
\hline Dead/ill & $2.1 \%$ & $2.1 \%$ & $2.1 \%$ & $2.3 \%$ & $2.2 \%$ & $2.3 \%$ \\
\hline Lives elsewhere & $10.4 \%$ & $10.0 \%$ & $10.8 \%$ & $9.8 \%$ & $9.8 \%$ & $9.8 \%$ \\
\hline Not found & $8.3 \%$ & $6.4 \%$ & $10.3 \%$ & $7.7 \%$ & $6.6 \%$ & $8.9 \%$ \\
\hline Not home & $7.9 \%$ & $8.7 \%$ & $7.2 \%$ & $8.2 \%$ & $8.7 \%$ & $7.6 \%$ \\
\hline Refused & $7.9 \%$ & $6.3 \%$ & $9.6 \%$ & $7.2 \%$ & $6.9 \%$ & $7.5 \%$ \\
\hline
\end{tabular}

Notes: Interview completion percentages from surveyor reports.

Table 4: Religion

\begin{tabular}{|c|c|c|c|}
\hline & & ES Coeffic & ients \\
\hline & Base & Controls & $\begin{array}{c}\text { Restricted } \\
\text { Sub-Sample }\end{array}$ \\
\hline (1) Regarded as Religious & $0.238^{* * *}$ & $0.230^{* * *}$ & $0.258^{* * *}$ \\
\hline & $(0.06)$ & $(0.055)$ & $(0.061)$ \\
\hline (2) Global Islamic Practice & $0.163^{* * *}$ & $0.166^{* * *}$ & $0.171^{* * *}$ \\
\hline & $(0.030)$ & $(0.029)$ & $(0.033)$ \\
\hline (3) Belief in Localized Muslim Practices & $-0.101 * * *$ & $-0.094 * * *$ & $-0.074 * *$ \\
\hline & $(0.032)$ & $(0.031)$ & $(0.035)$ \\
\hline (4) Participation in Localized Muslim Practices & $-0.097 * *$ & $-0.097 * *$ & $-0.085^{*}$ \\
\hline & $(0.046)$ & $(0.045)$ & $(0.052)$ \\
\hline
\end{tabular}

Notes: Columns give AES estimates for our base, control, and restricted subsample specifications. The AES averages the normalized treatment effects obtained from a seemingly unrelated regression in which each dependent variable is a question in the index. All regressions include dummies for place of departure $\mathrm{X}$ accomodation category $\mathrm{X}$ party size category, as well as dummies for each of the 9 districts in the survey. All results come from IV regressions where the instrument is success in the Hajj lottery. Standard errors in parentheses clustered at the party level: * significant at 10\%; ** significant at 5\%; *** significant at $1 \%$.

Index component questions with number of components indicated in parentheses. Index 1(1): Do others regard you as religious? Index 2(10): How frequently do you: pray, do tasbih after prayer, pray in mosque? Did you pray in mosque last Sunday? Do you pray optional night prayer? Can you read Qu'ran? How frequently do you: read Qu'ran? discuss religious matters? keep fast during Ramadan? keep fast outside Ramadan? Index 3(10): What is general view of holy men? Do you regard as correct: visiting holy men? visiting shrines? using amulets? doing 40-day death ceremony? participating in maulad mehfil (special religious gathering)? Do you believe that: a cap is required for prayer? that dowry is mandatory? that widows have different priority in remarriage? that there can be intercession on Judgement Day? Index 4(4): Do you actively visit holy men? visit shrines? uses amulets? participate in maulad mehfil? 
Table 5: Tolerance

\begin{tabular}{llll} 
& \multicolumn{3}{c}{ AES Coefficients } \\
\cline { 2 - 4 } & & \multicolumn{2}{c}{$\begin{array}{l}\text { Restricted } \\
\text { Sub-Sample }\end{array}$} \\
\hline (1) Views of Other Countries & Base & Controls & $0.151^{* * *}$ \\
(2) Views of Other Groups & $(0.04)$ & $(0.04)$ & $(0.04)$ \\
& $0.131^{* * *}$ & $0.108^{* *}$ & $0.122 * *$ \\
(3) Harmony & $(0.05)$ & $(0.05)$ & $(0.06)$ \\
& $0.128^{* * *}$ & $0.117^{* * *}$ & $0.126^{* * *}$ \\
(4) Peaceful Inclination & $(0.04)$ & $(0.04)$ & $(0.05)$ \\
(5) Political Islam Index & $0.111^{* * *}$ & $0.121^{* * *}$ & $0.128^{* * *}$ \\
& $(0.03)$ & $(0.03)$ & $(0.04)$ \\
(6) Views of West & -0.050 & -0.044 & -0.043 \\
& $(0.04)$ & $(0.03)$ & $(0.04)$ \\
\end{tabular}

Notes: See notes to Table 4

Index component questions with number of components indicated in parentheses. Index 1(6): General view of people from other countries, positive to negative: Saudis, Indonesians, Turks, African, Europeans, Chinese. Index 2(3): How do members of following groups compare to your group: different sect? different religion? different ethnicity? Index 3(4): Do you believe following groups can live in unity and harmony through compromise over disagreements: sects of Islam? religions? Pakistani ethnic groups? Do you ever pray in a mosque of a different school of thought? Index 4(8): Belief in incorrectness of: Osama's goals? Osama's methods? How important is peace with India for Pakistan? Should current India/Pakistan boundary be permanent border if leads to peace? Should Pakistan not support/only partly support those fighting Indian government in Kashmir? How incorrect are: suicide attacks? attacks on civilians in war? physical punishment of someone who dishonors family? Index 5(5): Agree that: government should enforce Islamic injunctions? religious leaders have right to dispense justice? religious leaders should have direct influence on government? better for politicians/officials to have strong religious beliefs? religious beliefs important in voting for candidate? Index 6(4): Is it bad for Pakistanis to adopt: Western social values? Western technology? Believe there was Western/Jewish role in 9/11 and 2005 London bombing? Believe West does not take into account interests of countries such as Pakistan?

\section{Table 6: Gender}

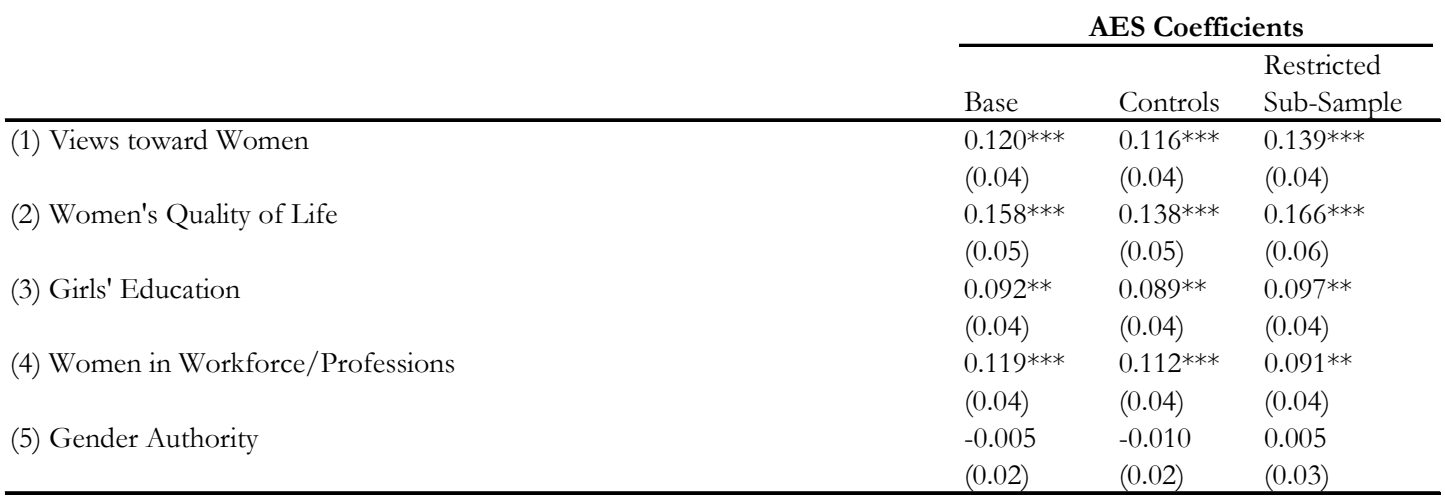

Notes: See notes to Table 4.

Index component questions with number of components indicated in parentheses. Index 1(4): How do men and women compare: mentally/intellectually? spiritually? morally/ethically? Are men and women equal? Index 2(5): Opinion of quality of women's lives in following countries/regions relative to Pakistan: Saudi Arabia, Indonesia/Malaysia, West. Think too many crimes against women in Pakistan: overall? relative to men? Index 3(5): Should girls attend school? Until what level would permit attendance at coeducational schools for: girls? boys? Until what level should coeducational schools be allowed? How many years should girls study relative to boys? Index 4(3): Like daughers/granddaughter to work? Like a professional occupation for daughers/granddaughters? Good employment important for daughter/granddaughter-in-law? Index 5(7): Women better at managing daily affairs? Wives have equal say in deciding number of children? Is it sometimes correct for: woman to divorce husband? marry against parents wishes? When jobs scarce men should not have more right to one than women? Should daughter have equal inheritence share? Do women count equally to men as witnesses? 
Table 7: Well-Being

\begin{tabular}{|c|c|c|c|c|c|}
\hline & \multicolumn{3}{|c|}{ Panel A: AES Coefficients } & \multicolumn{2}{|c|}{ Panel B: AES } \\
\hline & Base & Controls & $\begin{array}{l}\text { Restricted } \\
\text { Sub-Sample }\end{array}$ & $\begin{array}{l}\text { Main } \\
\text { Effect }\end{array}$ & $\begin{array}{l}\text { Male } \\
\text { Interaction }\end{array}$ \\
\hline (1) Rescaled K6 Index & $\begin{array}{l}-0.206^{* * *} \\
(0.05)\end{array}$ & $\begin{array}{l}-0.206^{* * *} \\
(0.05)\end{array}$ & $\begin{array}{l}-0.200^{* * *} \\
(0.05)\end{array}$ & $\begin{array}{l}-0.369 * * * \\
(0.08)\end{array}$ & $\begin{array}{l}0.326^{* * *} \\
(0.09)\end{array}$ \\
\hline (2) Positive Feelings & $\begin{array}{l}-0.109 * * \\
(0.05)\end{array}$ & $\begin{array}{l}-0.098^{* *} \\
(0.04)\end{array}$ & $\begin{array}{l}-0.079 \\
(0.05)\end{array}$ & $\begin{array}{l}-0.149 * * \\
(0.07)\end{array}$ & $\begin{array}{l}0.079 \\
(0.08)\end{array}$ \\
\hline (3) Index of Satisfaction with Life and Finances & $\begin{array}{l}-0.010 \\
(0.04)\end{array}$ & $\begin{array}{l}0.006 \\
(0.04)\end{array}$ & $\begin{array}{l}0.011 \\
(0.04)\end{array}$ & $\begin{array}{l}-0.028 \\
(0.05)\end{array}$ & $\begin{array}{l}0.036 \\
(0.08)\end{array}$ \\
\hline (4) Self-Rated Physical Health & $\begin{array}{l}-0.213^{* * *} \\
(0.05)\end{array}$ & $\begin{array}{l}-0.219 * * * \\
(0.05)\end{array}$ & $\begin{array}{l}-0.239 * * * \\
(0.06)\end{array}$ & $\begin{array}{l}-0.320 * * * \\
(0.07)\end{array}$ & $\begin{array}{l}0.210^{* *} \\
(0.10)\end{array}$ \\
\hline
\end{tabular}

Notes: See notes for Table 4. In addition, note that Panel A gives AES estimates for our base, control, and restricited subsample specifications while Panel B adds a interaction between Haji participation and a male variable to the base AES specification. In Panel $\mathrm{B}$, the instruments are success in the Hajj lottery for the main effect and success interacted with male in the interaction specification. Index component questions with number of components indicated in parentheses. Index 1(6):[rescaled, high value=less distress] During the past 30 days, how often did you feel: nervous? hopeless? restless or fidgety? so depressed that nothing could cheer you up? everything was an effort? worthless? Index 2(5): During the past 30 days, how often did you feel: relaxed and peaceful? content? joyous? How much pleasure do you take in life? Altogether, are you very happy/not at all happy (4 point scale)? Index 3(3): How satisfied with life as a whole are you (10 point scale)? How much room for improvement in your quality of life? How satisfied are you with finances (10 point scale)? Index 4(2): How good is your physical health (4 point scale)? Have you been free of any 7-plus day illness/injury in past year?

Table 8: Engagement and Exposure

\begin{tabular}{llll} 
& & \multicolumn{2}{c}{ AES Coefficients } \\
& & Controls & $\begin{array}{l}\text { Restricted } \\
\text { Sub-Sample }\end{array}$ \\
\hline (1) Socioeconomic Engagement & Base & -0.008 & 0.011 \\
& -0.002 & $(0.02)$ & $(0.02)$ \\
(2) Engagement in Politics & $(0.02)$ & -0.010 & -0.024 \\
& -0.011 & $(0.03)$ & $(0.03)$ \\
(3) Formal Knowledge of Islam & $(0.03)$ & 0.000 & -0.003 \\
& 0.004 & $(0.03)$ & $0.04)$ \\
(4) Diversity Knowledge & $(0.04)$ & $0.139^{* * *}$ & $0.133^{* * *}$ \\
(5) Gender Knowledge & $0.146^{* * *}$ & $(0.04)$ & $0.05)$ \\
& $(0.04)$ & $0.116^{* * *}$ & $0.104^{* *}$ \\
(6) Global Knowledge & $0.125^{* * *}$ & $(0.03)$ & $(0.04)$ \\
\end{tabular}

Notes: See notes for Table 4.

Index component questions with number of components indicated in parentheses. Index 1(15): How frequently do you visit: people in your town/village? people outside your town/village? How frequently are you visited by: people in your town/village? people from outside your town/village? How many times in the past year have close family/friends sought advice on: family matters? religious matters? business matters? How many times in the past year have more distance family/friends sought advice on: family matters? religious matters? business matters? Are you a member of following kinds of organizations: religious, professional, school? Do you work as: an employee? for yourself? Index 2(7): Did you vote in last election? How interested in national affairs? Are you member of political party? Are you member of political organization? A social organization? How often do you follow national affairs? Do you have an opinion on how politicians are handling national affairs? Index 3(10): Name as many of five pillars of Islam as you can. Correct answer to: How many chapters in Qu'ran? Can you recite favorite verse of Qu'ran? What is shortest sura of Qu'ran? What is longest? How many suras are in the Qu'ran? What is first revealed verse of Qu'ran? Is method of prayer described in Qu'ran? What is percentage required to be given as Zakat (charitable tax)? How long must wealth be held for Zakat to be due? Index 4(3): Correct answers to: How many accepted schools of thought in Sunni Islam? Is a cap required for prayer? Is saying "talak, talak, talak" sufficient for legal divorce? Index 5(8): Correct answers to: What was name of prophet's first wife? How many wives is a man allowed at once? Can a Muslim man marry a Jewish or Christian woman? Is dowry mandatory? Further: Have you heard of Islamic law relating to adultery? Do you have an opinion about women's lives in: Saudi Arabia? Indonesia/Malaysia? West? Index 6(6): How many countries share a border with Pakistan? What country has largest percentage Muslim? What percentage of Nigerians are Muslim? What are world's two most populous countries? Who is Prime Minister of India? Which is further from Pakistan, England or United States? 
Table 9: Selected Survey Questions

\begin{tabular}{|c|c|c|c|c|c|c|c|}
\hline Row & Question & Coding & Coef. & P-Value & $\begin{array}{l}\text { Comp. } \\
\text { Mean }\end{array}$ & Obs. & $\mathbf{R}^{2}$ \\
\hline 1 & Do you believe others regard you as religious & $1=$ Religious, $0=$ Not Religious & 0.100 & 0.000 & 0.772 & 1541 & 0.033 \\
\hline 2 & Do you pray “Tahajjud Namaz”? & $\begin{array}{l}1=\text { Yes (regularly, occasionally), } 0=\text { No } \\
\text { (rarely, never) }\end{array}$ & 0.184 & 0.000 & 0.281 & 1605 & 0.047 \\
\hline 3 & $\begin{array}{l}\text { How often did you fast outside of Ramadan during the } \\
\text { past year? }\end{array}$ & $\begin{array}{l}1=\text { Several times per month or more, } \\
0=\text { Once per month or less }\end{array}$ & 0.041 & 0.006 & 0.049 & 1605 & 0.030 \\
\hline 4 & Is your general view of Indonesian people: & $2=$ Very Positive, $-2=$ Very Negative & 0.217 & 0.000 & 0.362 & 1583 & 0.055 \\
\hline 5 & Is your general view of Saudi people: & $2=$ Very Positive, $-2=$ Very Negative & 0.110 & 0.026 & 1.034 & 1593 & 0.026 \\
\hline 6 & $\begin{array}{l}\text { In your opinion, overall how are people of a different } \\
\text { religion compared to your people? }\end{array}$ & $0=$ Better or Worse, $1=$ Same & 0.084 & 0.004 & 0.389 & 1604 & 0.025 \\
\hline 7 & $\begin{array}{l}\text { Do you believe that people of different religions can } \\
\text { live in unity \& agreement (harmony) in a given society } \\
\text { by making agreements over their differences? }\end{array}$ & $1=\mathrm{Yes}, 0=\mathrm{No}$ & 0.063 & 0.074 & 0.589 & 1270 & 0.036 \\
\hline 8 & $\begin{array}{l}\text { Do you ever pray in the mosque of a different maslak } \\
\text { than your own? }\end{array}$ & $\begin{array}{l}\text { Binary: } 1=\text { Frequently, } 0=\text { Less } \\
\text { Often/Never }\end{array}$ & 0.034 & 0.021 & 0.049 & 1463 & 0.027 \\
\hline 9 & $\begin{array}{l}\text { Do you believe the goals for which Ossama is fighting } \\
\text { are correct? }\end{array}$ & $\begin{array}{l}1=\text { Not Correct at All/Slightly Incorrect, } \\
0=\text { Correct } / \text { Absolutely Correct }\end{array}$ & 0.063 & 0.014 & 0.068 & 761 & 0.054 \\
\hline 10 & $\begin{array}{l}\text { Do you believe the methods Ossama uses in fighting } \\
\text { are correct? }\end{array}$ & $\begin{array}{l}1=\text { Absolutely Never/Almost Never } \\
\text { Correct, } 0=\text { To Small Extent/Some } \\
\text { Extent/Strongly Correct }\end{array}$ & 0.051 & 0.112 & 0.159 & 761 & 0.063 \\
\hline 11 & $\begin{array}{l}\text { How important do you believe peace with India is for } \\
\text { Pakistan's future? }\end{array}$ & $1=$ Important, $0=$ Not Important & 0.044 & 0.016 & 0.913 & 1155 & 0.020 \\
\hline 12 & $\begin{array}{l}\text { Please tell me what you think about the correctness of } \\
\text { the following: Family members physically punishing } \\
\text { someone who has dishonored the family }\end{array}$ & $0=$ Correct, $1=$ Never Correct & 0.044 & 0.112 & 0.261 & 1459 & 0.033 \\
\hline 13 & $\begin{array}{l}\text { In your opinion, how do men and women compare to } \\
\text { each other with respect to the following traits: } \\
\text { Spiritually }\end{array}$ & $\begin{array}{l}0=\text { Men are Better/Equal, } 1=\text { Women are } \\
\text { Better }\end{array}$ & 0.057 & 0.006 & 0.111 & 1497 & 0.034 \\
\hline 14 & $\begin{array}{l}\text { What is your opinion about the quality of women's } \\
\text { lives in each of the following countries/regions? } \\
\text { Indonesia/ Malaysia }\end{array}$ & $\begin{array}{l}1=\text { Greater than in Pakistan, } 0=\text { Lower than } \\
\text { or equal that in Pakistan; Base variables } \\
5=\text { Very High, } 1=\text { Very Low }\end{array}$ & 0.094 & 0.088 & 0.262 & 551 & 0.058 \\
\hline 15 & $\begin{array}{l}\text { What is your opinion about the quality of women's } \\
\text { lives in each of the following countries/regions? Saudi } \\
\text { Arabia }\end{array}$ & $\begin{array}{l}1=\text { Greater than in Pakistan, } 0=\text { Lower than } \\
\text { or equal that in Pakistan; Base variables } \\
5=\text { Very High, } 1=\text { Very Low }\end{array}$ & 0.051 & 0.145 & 0.322 & 1180 & 0.048 \\
\hline 16 & $\begin{array}{l}\text { What is your opinion about the quality of women's } \\
\text { lives in each of the following countries/regions? West }\end{array}$ & $\begin{array}{l}1=\text { Greater than in Pakistan, } 0=\text { Lower than } \\
\text { or equal that in Pakistan; Base variables } \\
5=\text { Very High, } 1=\text { Very Low }\end{array}$ & 0.087 & 0.051 & 0.186 & 646 & 0.091 \\
\hline 17 & $\begin{array}{l}\text { Do you think there are too many crimes against } \\
\text { Women in Pakistan? Overall }\end{array}$ & Binary: $0=\mathrm{No}, 1=$ Yes & 0.052 & 0.075 & 0.597 & 1605 & 0.045 \\
\hline 18 & $\begin{array}{l}\text { Do you think there are too many crimes against } \\
\text { Women in Pakistan? Relative to Men }\end{array}$ & $\begin{array}{l}\text { 1=Against Women Score }<\text { Against Men } \\
\text { Score, } 0=\text { Against Women Score }>=\text { Against } \\
\text { Men Score; Base scores } 1=\text { Yes, a lot; } \\
4=\text { No, not at all }\end{array}$ & 0.053 & 0.052 & 0.171 & 1135 & 0.026 \\
\hline 19 & In your opinion, girls should attend school & Binary: $0=$ Disagree, $1=$ Agree & 0.028 & 0.039 & 0.933 & 1604 & 0.027 \\
\hline 20 & $\begin{array}{l}\text { Until what level would you prefer allow/permit girls in } \\
\text { your family to attend coeducational schools(boys and } \\
\text { girls in the same school)? }\end{array}$ & $\begin{array}{l}0=\text { Never, } 1=\text { Primary, Secondary, or All } \\
\text { Levels }\end{array}$ & 0.055 & 0.036 & 0.722 & 1550 & 0.035 \\
\hline 21 & $\begin{array}{l}\text { Until what level would you prefer allow/permit boys } \\
\text { in your family to attend coeducational schools (boys } \\
\text { and girls in the same school)? }\end{array}$ & $\begin{array}{l}0=\text { Never, } 1=\text { Primary, Secondary, or All } \\
\text { Levels }\end{array}$ & 0.059 & 0.024 & 0.729 & 1550 & 0.036 \\
\hline 22 & $\begin{array}{l}\text { Would you like for your daughters or female } \\
\text { grandchildren to have a career other than caring for the } \\
\text { household? }\end{array}$ & $0=\mathrm{No}, 1=\mathrm{Yes}$ & 0.045 & 0.156 & 0.540 & 1605 & 0.029 \\
\hline 23 & $\begin{array}{l}\text { How important are the following characteristics in your } \\
\text { son's, grandson's wife?: Good Employment or } \\
\text { Business }\end{array}$ & $0=$ Not Important, $1=$ Important & 0.054 & 0.073 & 0.457 & 1562 & 0.028 \\
\hline
\end{tabular}

Notes: Rows contain results from individual IV regressions where the instrument is success in the Hajj lottery, and which include include dummies for place of departure X accomodation category X party size category. P-values are corrected for clustering at the party level. 


\section{APPENDIX}

Outline of the Hajj Pilgrimage

OVERALL TIME IN SAUDI ARABIA: 40 DAYS

\begin{tabular}{|c|c|c|c|c|c|c|c|}
\hline AFTER ARRIVAL & \multicolumn{6}{|c|}{$\begin{array}{l}\text { FORMAL RITUALS OF THE HAJJ--ALL PILGRIMS FROM ALL NATIONS PARTICIPATE SIMULTANEOUSLY, } \\
\text { 5 DAYS }\end{array}$} & $\begin{array}{c}\text { BEFORE } \\
\text { DEPARTURE } \\
\end{array}$ \\
\hline \multirow{5}{*}{$\begin{array}{l}\text { Pakistani pilgrims } \\
\text { have a staggered } \\
\text { arrival up to } 35 \text { days } \\
\text { before the formal } \\
\text { rituals of the Hajj. } \\
\text { During this time, they } \\
\text { typically perform } \\
\text { umrah and pray in the } \\
\text { Masjid al-Haram in } \\
\text { Mecca. If they will not } \\
\text { be in the country for } \\
\text { long after the formal } \\
\text { rituals, they may visit } \\
\text { Medina, though this is } \\
\text { typically done after. }\end{array}$} & & Day 1 & Day 2 & Day 3 & Day 4 & Day 5 & \multirow{5}{*}{$\begin{array}{l}\text { Pakistani pilgrims } \\
\text { have a staggered } \\
\text { departure up to } 35 \\
\text { days following the } \\
\text { formal rituals of the } \\
\text { Haij. During this } \\
\text { time, they typically } \\
\text { make a trip to } \\
\text { Medina for several } \\
\text { days, where they } \\
\text { pray at the prophet's } \\
\text { mosque, the Masjid } \\
\text { al-Nabawi. The trip } \\
\text { to Medina is } \\
\text { common for all } \\
\text { nations. Outside this } \\
\text { time, they perform } \\
\text { umrab and pray in } \\
\text { the Masjid al-Haram } \\
\text { in Mecca. }\end{array}$} \\
\hline & Morning & $\begin{array}{l}\text { Ibram garments are } \\
\text { donned. } \\
\text { Tawaf and sa'y are } \\
\text { performed in the } \\
\text { Masjid al-Haram in } \\
\text { Mecca. }\end{array}$ & $\begin{array}{l}\text { Travel to Mount Arafat at } \\
\text { dawn, 25-30 kilometers away. }\end{array}$ & $\begin{array}{l}\text { Travel to Mina from } \\
\text { Muzadalifah. } \\
\text { Participate in jamarat ritual. } \\
\text { Pilgrims symbolically "stone the } \\
\text { devil" by throwing the pebbles } \\
\text { they have collected at three } \\
\text { pillars.. }\end{array}$ & $\begin{array}{l}\text { Return to Mina if } \\
\text { night spent in } \\
\text { Mecca. }\end{array}$ & & \\
\hline & Afternoon & $\begin{array}{l}\text { Travel to the town of } \\
\text { Mina, 5-6 kilometers } \\
\text { away. } \\
\text { Rest, prayer, and } \\
\text { reading of the } \\
\text { Qu'ran. }\end{array}$ & $\begin{array}{l}\text { Stay on plain of Arafat until } \\
\text { sunset in prayer and } \\
\text { contemplation. }\end{array}$ & $\begin{array}{l}\text { Sacrifice an animal. The meat is } \\
\text { given to the poor. A voucher } \\
\text { may be purchased for this. } \\
\text { Pilgrims released from most } \\
\text { ibram restrictions. They have } \\
\text { their heads shaved. }\end{array}$ & $\begin{array}{l}\text { Complete jamarat } \\
\text { ritual, stoning all } \\
\text { three pillars in } \\
\text { Mina. }\end{array}$ & $\begin{array}{l}\text { Complete jamarat ritual, } \\
\text { again stoning all three } \\
\text { pillars in Mina. } \\
\text { Pilgrims must leave Mina } \\
\text { for Mecca by sunset. } \\
\text { Otherwise they must } \\
\text { repeat the jamarat the } \\
\text { following day before } \\
\text { returning. }\end{array}$ & \\
\hline & Night & \begin{tabular}{l|} 
Spend night in tents \\
at Mina.
\end{tabular} & $\begin{array}{l}\text { After sunset, begin journey to } \\
\text { Muzdalifah, about } 15 \\
\text { kilometers away. }\end{array}$ & $\begin{array}{l}\text { Return to Masjid al-Haram to } \\
\text { perform tawaf. Pilgrims may also } \\
\text { do this the morning of the fourth } \\
\text { day. }\end{array}$ & $\begin{array}{l}\text { Spend night in } \\
\text { Mina. }\end{array}$ & $\begin{array}{l}\text { Spend night in Mecca. } \\
\text { Pilgrims perform a } \\
\text { farewell tawaf before } \\
\text { leaving Mecca. }\end{array}$ & \\
\hline & & & $\begin{array}{l}\text { Spend night in the open at } \\
\text { Muzadalifah. } \\
\text { Pray and collect pebbles for } \\
\text { jamarat the next day. }\end{array}$ & $\begin{array}{l}\text { Spend night in either Mecca or } \\
\text { Mina. }\end{array}$ & & & \\
\hline
\end{tabular}

Tawaf: Four quick circumambulations of the ka'ba followed by three leisurely circumambulations. Pilgrims say a set of prayers as they walk.

Sa'y: Walking seven times back and forth between the hills of Safa and Marwah, now enclosed in the Masjid al-Haram.

Umrab: A minor pilgrimage that can be done at any time, consisting of a tawaf and sa' $y$ while wearing the ihram. 